\title{
POPULATION VARIABILITY OF SCOTS PINE (PINUS SYLVESTRIS L.) IN TURKEY ACCORDING TO THE NEEDLE MORPHOLOGY
}

\author{
VARIJABILNOST POPULACIJA OBIČNOG BORA \\ (PINUS SYLVESTRIS L.) U TURSKOJ PREMA MORFOLOŠKIM \\ OBILJEŽJIMA IGLICA
}

\author{
Arzu ERGÜL BOZKURT ${ }^{*}$, Kamil COŞKUNÇELEBI ${ }^{2}$, Salih TERZIOĞLU³
}

\begin{abstract}
SUMMARY
In the present study, needle variation of Scots pine (Pinus sylvestris L., Pinaceae) populations in Turkey was investigated. From selected eight populations, a total of 1314 needles belonging to 206 trees were examined. Four morphological needle traits were measured and analyzed to describe the population diversity and differentiation. Analyzed morphological traits showed significant variability. The trees within populations differ significantly in all analyzed needle characteristics, while the differences between populations were significant for the three of four studied characteristics. Present findings revealed that needle length, needle width and the ratio of needle length to needle width showed clinal variation in response to altitudinal gradients. Populations from higher altitudes were characterized with the smaller and wider needles as compared to the populations from lower altitudes. The results of this study could be valuable baseline data for the development of more efficient management plans for this forest tree species.
\end{abstract}

KEY WORDS: Scots pine, population variability, needle characteristics, morphometric analysis, clinal variation

\section{INTRODUCTION}

\section{UVOD}

Scots pine (Pinus sylvestris L., family Pinaceae) is one of the most important timber and forest tree species globally (Koprowski et al. 2012). It has a very wide distribution in Europe and Asia due to its high degree of ecological tolerance (Alemdağ 1967; Pehlivan 2010). The tree is tolerant to poor soils, drought, and frost. It is a pioneer species, able to colonize nutrient-poor soils in disturbed areas (Mátyás et al. 2004; Houston Durrant et al. 2016). Scots pine frequently grows in large single species stands in altitudes ranging from sea level up to 2600 MASL. However, across its huge range it may also be found in mixed stands with most of the boreal tree species of Europe and Asia.

Scots pine is the third-most dominant conifer tree species in Turkey (Kandemir and Matarac1 2018). Its distribution in Turkey extends from Pınarbaşı to Ayancık in the longitudinal, and Orhaneli to Kağızman in the latitudinal directions (Saatçioğlu 1944; Kayacık 1954; Pamay 1962). The geographical limits of the southeastern distribution of Scots pine have been reported in the Pınarbaş1 district of the Kayseri province of Turkey (Demirci 2006; Pehlivan 2010). P.

\footnotetext{
${ }^{1 *}$ Asst.Prof. Arzu Ergül Bozkurt, Artvin Çoruh University, Faculty of Forestry, Department of Forest Botany, Artvin, Turkey;

2 Prof.Dr. Kamil Coşkunçelebi, Karadeniz Technical University, Faculty of Sciences, Department of Biology, Trabzon, Turkey;

3 Prof.Dr. Salih Terzioğlu, Karadeniz Technical University, Faculty of Forestry, Department of Forest Botany, Trabzon, Turkey;

e-mail for the *corresponding author: ergul_arzu@yahoo.com
} 
sylvestris grows from sea level (along the Black Sea) to 3125 MASL in the Allahuekber Mountains of Eastern Anatolia (Eliçin 1971).

Wide geographical distribution resulted with considerable morphological and genetic diversity within P. sylvestris (Wright and Bull 1963; Pravdin 1969; Ruby 1967; Mirov 1967; Szmidt 1984; Wang et al. 1991; Androsiuk et al. 2011; Jasińska et al. 2014; Dering et al. 2017). Variation observed in its needle and cone characteristics resulted in the description of several subspecies and varieties (Gaussen 1960; Mirov 1967; Farjon 2008; Jasińska et al. 2014). Farjon (2008) reported the existence of three varieties of $P$. sylvestris: var. sylvestris, var. mongolica Litv., and var. hamata Steven. According to Farjon (2008), the distribution range of the var. sylvestris and var. hamata extend through Turkey. In addition, Kandemir and Matarac1 (2018) described a new variety, var. elicinii Kandemir and Matarac1, from Turkey mainly based on needle length and color.

Jasińska et al. (2014) detected morphological differences between the East and West Anatolian populations of P. sylvestris. Similar results were also reported by Bilgen and Kaya (2007). The isolation of the eastern from western Anatolian populations was explained by the mountain ranges known as the "Anatolian diagonal". In addition, Jasińska et al. (2014) stated that morphological pattern of diversity in Anatolian populations of the Scots pine may also be a result of: (1) another origin source - the western populations from the Balkans and the eastern ones from the Caucasus; and (2) different rates of evolution in the two regions. Furthermore, Dering et al. (2017) revealed strong spatial genetic structure within the Scots pine range, involving four distinct groups well related to the LPG refugial areas previously defined for this species (Naydenov et al. 2007; Pyhäjärvi et al. 2008; Sinclair et al. 1998, 1999). Authors revealed that two most spatially restricted groups of populations correspond to Scots pine refugia located on the Iberian and Asia
Minor Peninsulas. Those populations represent the valuable relict genetic resources that are of high conservation priority (Naydenov et al. 2007; Pyhäjärvi et al. 2008; Dering et al. 2017).

The aim of the present study is to assess needle size variation among Scots pine populations of Turkey and identify relationships with respect to altitude.

\section{MATERIAL AND METHODS MATERIJAL I METODE}

Samples for morphometric analysis were collected from eight natural Scots pine populations in Turkey (Table 1). Needles were sampled from 14 to 31 trees per population, and each individual tree was represented by 5 to 10 needles from well-grown shoots. In total 1314 needles belonging to 206 individuals were analyzed. The following traits were included in the analysis: needle length, needle width, needle length/needle width ratio, and sheath length.

Minimal and maximal values of characteristics were determined, and arithmetical means, standard deviation and variation coefficients were calculated and analyzed for each population. Analysis of variance (ANOVA) was performed to determine the statistically significant differences between populations and between trees within populations.

The relationship between average values of morphological needle traits and altitude (e.g. Krauze-Michalska and Boratyńska 2013; Poljak et al. 2015, 2018) were tested using Spearman's coefficient (Sokal and Rohlf 2012).

Multivariate statistical methods were used to identify the population differentiation (McGarigal et al. 2000; Zebec et al. 2010; Poljak et al. 2012, 2018): cluster analysis and discriminant analysis. The conducted cluster analysis resulted in a hierarchical tree, where the unweighted pair-group method with arithmetic mean (UPGMA) was used to join

Table 1. Sampled populations.

Tablica 1. Uzorkovane populacije.

\begin{tabular}{|c|c|c|c|c|}
\hline $\begin{array}{l}\text { Populations } \\
\text { Populacije }\end{array}$ & $\begin{array}{l}\text { Total number } \\
\text { of trees } \\
\text { Ukupan broj } \\
\text { stabala }\end{array}$ & $\begin{array}{l}\text { Nadmorska } \\
\text { visina }(\mathrm{m}) \\
\text { Altitude }(\mathrm{m})\end{array}$ & $\begin{array}{l}\text { Geographical region of Turkey } \\
\text { (Kantarcı 2005) } \\
\text { Geografska regija Turske } \\
\text { (Kantarcı 2005) }\end{array}$ & $\begin{array}{l}\text { Habitat zones (Kantarcı 2005) } \\
\text { Stanišne zone (Kantarcı 2005) }\end{array}$ \\
\hline Ardahan-Yalnızçam (AY) & 30 & $1850-2300$ & Eastern Anatolia & Habitat zone of the Kars \\
\hline Artvin-Arhavi, Hopa (AH) & 14 & $0-600$ & Black Sea & $\begin{array}{l}\text { Habitat zone of the Rize - Kaçkar Mountains, } \\
\text { Rize-Hopa Sub-Region }\end{array}$ \\
\hline Trabzon-Sürmene (TS) & 15 & $0-450$ & Black Sea & Habitat zone of the Trabzon Mountains \\
\hline Giresun-Espiye (GE) & 30 & $1600-2200$ & Black Sea & Habitat zone of the Canik - Giresun Mountains \\
\hline Kastamonu-Taşköprü (KT) & 30 & $1200-1800$ & Black Sea & \multirow{2}{*}{ Habitat zone of the Mountainous area } \\
\hline Bolu - Aladağ (BA) & 31 & $1200-1800$ & Black Sea & \\
\hline Ankara- Çamlıdere (AC) & 26 & $1400-2000$ & Central Anatolia & Habitat zone of behind the Western Black Sea Region \\
\hline Eskişehir-Çatacık (EC) & 30 & $1200-1800$ & Central Anatolia & Habitat zone of the West Central Anatolia \\
\hline
\end{tabular}


Table 2. Descriptive statistical parameters for measured morphological traits. Needle length (NL), needle width (NW), ratio of needle length to width (NL/NW), sheath length (SL), standard deviations (SD), coefficients of variability (CV).

Tablica 2. Deskriptivni statistički parametri za mjerene morfološke značajke. Dužina iglice (NL), širina iglice (NW), omjer dužine i širine iglice (NL/NW), dužina rukavca (SL), standardna devijacija (SD), koeficijent varijabilnosti (CV).

\begin{tabular}{|c|c|c|c|c|c|c|c|c|c|}
\hline \multirow{2}{*}{$\begin{array}{l}\text { Trait } \\
\text { Značajka }\end{array}$} & \multirow{2}{*}{$\begin{array}{l}\text { Statistical } \\
\text { parameters } \\
\text { Deskriptivni } \\
\text { pokazatelji }\end{array}$} & \multicolumn{8}{|c|}{$\begin{array}{l}\text { Populations } \\
\text { Populacije }\end{array}$} \\
\hline & & AY & $\mathrm{AH}$ & TS & GE & KT & $\mathrm{BA}$ & $A C$ & $\mathrm{EC}$ \\
\hline \multirow{5}{*}{ NL } & mean & 5.41 & 7.09 & 7.59 & 4.49 & 4.74 & 4.25 & 4.34 & 5.13 \\
\hline & $\max$ & 7.70 & 9.50 & 13.20 & 7.45 & 11.10 & 6.40 & 6.40 & 7.10 \\
\hline & $\min$ & 3.50 & 5.50 & 4.10 & 2.10 & 2.55 & 2.40 & 1.85 & 3.40 \\
\hline & SD & 2.97 & 2.82 & 6.43 & 3.78 & 6.05 & 2.82 & 3.22 & 2.62 \\
\hline & CV (\%) & 54.90 & 39.77 & 84.72 & 84.19 & 127.64 & 66.35 & 74.19 & 51.07 \\
\hline \multirow{5}{*}{ NW } & mean & 1.56 & 1.42 & 1.37 & 1.64 & 1.32 & 1.43 & 1.38 & 1.30 \\
\hline & $\max$ & 2.04 & 1.94 & 1.73 & 2.26 & 1.82 & 1.83 & 2.07 & 1.84 \\
\hline & $\min$ & 1.27 & 1.24 & 1.18 & 1.13 & 1.06 & 1.14 & 1.07 & 0.93 \\
\hline & SD & .54 & .49 & .39 & .80 & .54 & .49 & .71 & .64 \\
\hline & CV (\%) & 34.62 & 34.51 & 28.47 & 48.78 & 40.91 & 34.27 & 51.45 & 49.23 \\
\hline \multirow{5}{*}{ NL/NW } & mean & 3.45 & 5.00 & 5.57 & 2.71 & 3.55 & 2.97 & 3.14 & 3.95 \\
\hline & $\max$ & 4.83 & 6.44 & 6.93 & 3.91 & 6.97 & 4.36 & 4.52 & 6.23 \\
\hline & $\min$ & 2.38 & 3.35 & 2.83 & 1.47 & 2.24 & 1.65 & 1.54 & 2.73 \\
\hline & SD & 1.73 & 2.18 & 2.90 & 1.73 & 3.34 & 1.92 & 2.11 & 2.47 \\
\hline & CV (\%) & 50.14 & 43.60 & 52.06 & 63.84 & 94.08 & 64.65 & 67.20 & 62.53 \\
\hline \multirow{5}{*}{ SL } & mean & 4.83 & 5.22 & 4.95 & 5.32 & 4.91 & 4.79 & 4.61 & 4.96 \\
\hline & $\max$ & 15.42 & 9.45 & 8.36 & 12.81 & 9.24 & 11.03 & 11.62 & 10.58 \\
\hline & $\min$ & 1.82 & 2.85 & 2.03 & 2.14 & 2.12 & 1.25 & 1.52 & 2.17 \\
\hline & SD & 9.62 & 4.67 & 4.48 & 7.54 & 5.03 & 6.92 & 7.14 & 5.95 \\
\hline & CV (\%) & 199.17 & 89.46 & 90.51 & 141.73 & 102.44 & 144.47 & 154.88 & 119.96 \\
\hline
\end{tabular}

the clusters, and the Euclidean distance to define the distance between the studied populations. For the discriminant analysis, standardized data were used. The plot was constructed by two discriminant functions showing analyzed individuals and populations.

The above statistical analyses were conducted using the SPSS Statistics 23.0 (Nie et al. 1975; IBM Corp 2015), SYNTAX 2000 (Podani 2001), and Past 3x (Hammer et al. 2001) statistical programs.

\section{RESULTS}

\section{REZULTATI}

Average values of needle characteristics of the 206 trees belonging to eight natural Scots pine populations from Turkey are given in Table 2. The highest mean values for needle length were observed in the two eastern populations TS and $\mathrm{AH}$. In contrast, the shortest needles were observed in the $A C ̧, G E$ and BA populations, respectively. Furthermore, the longest sheaths were observed in AH and GE populations, and the widest needles in AY and GE populations. In addition, the highest values for the ratio of needle length to needle width were observed in the populations AH and TS, and the lowest for the population GE.
As expected, strong correlations between needle morphological traits were observed. Almost all measured needle traits correlated with each other at a statistically significant level. Using Spearman's correlation coefficient, a highly positive correlation was found between altitude and needle width. On the other hand, needle length and the ratio of needle length to needle width were highly negatively correlated with the altitude.

The ANOVA revealed significant differences with respect to needle properties among the eight populations examined, with the exception of sheath length, which did not significantly differ among tested populations. The trees within populations differ significantly for all studied variables.

The structure of the eight Scots pine populations was inferred by the cluster analysis. The results are presented with the hierarchical tree (Figure 1), where the unweighted pair-group method with arithmetic mean (UPGMA) was used to join the clusters. The results clearly indicated that studied populations can be divided into three distinct subclusters. The first sub-cluster consisted only of GE population. The second sub-cluster consisted of AH and TS populations. Finally, the third sub-cluster consisted of the 


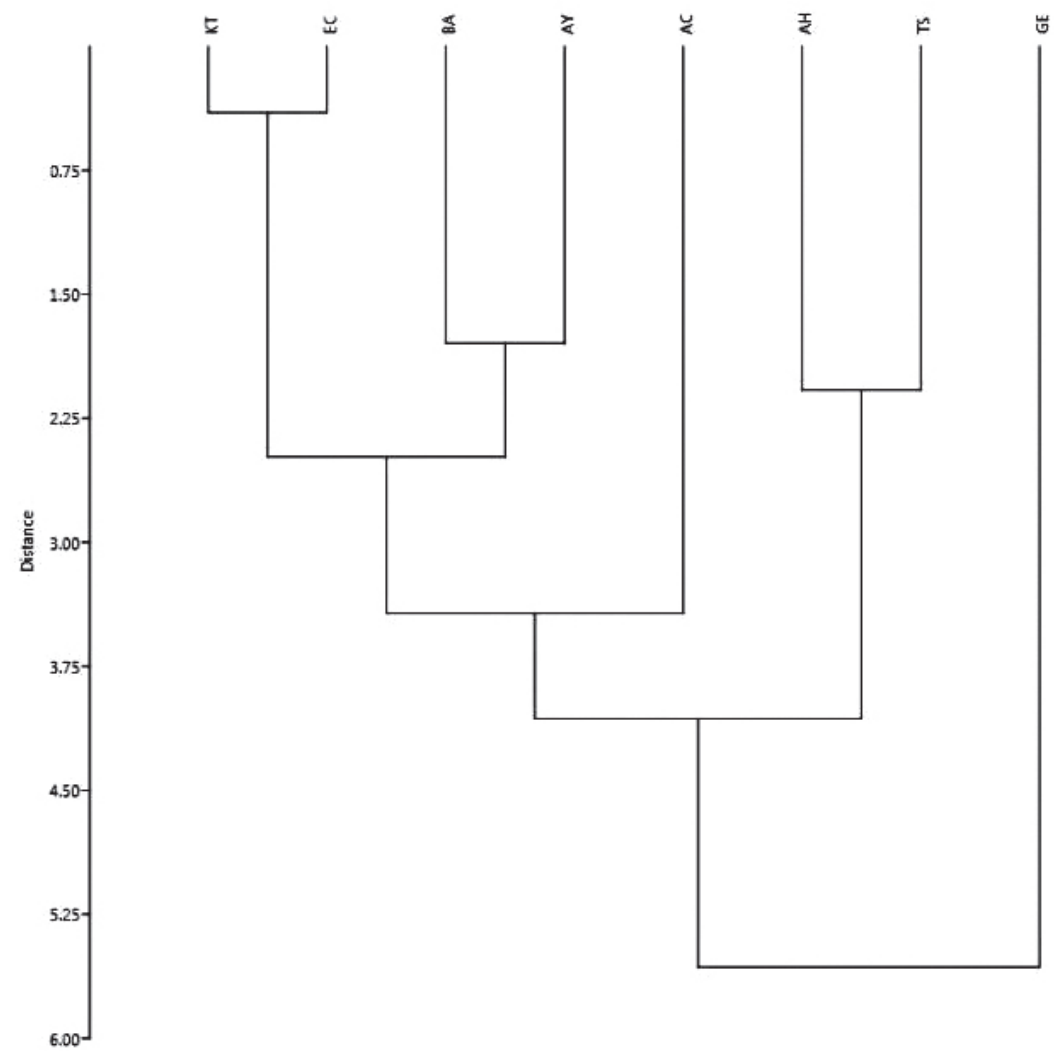

Figure 1. Horizontal hierarchical tree diagram.

Slika 1. Horizontalno hijerarhijsko stablo.

remaining five populations: $\mathrm{AC}, \mathrm{AY}, \mathrm{KT}, \mathrm{EC}, \mathrm{BA}$. As seen in Figure 1, the most similar populations were KT and EC, and the most distinct population was GE.
The results of the discriminant analysis are presented in two-dimensional plot in the Figure 2. The first discriminant function explained $65.2 \%$ of the total variation, and

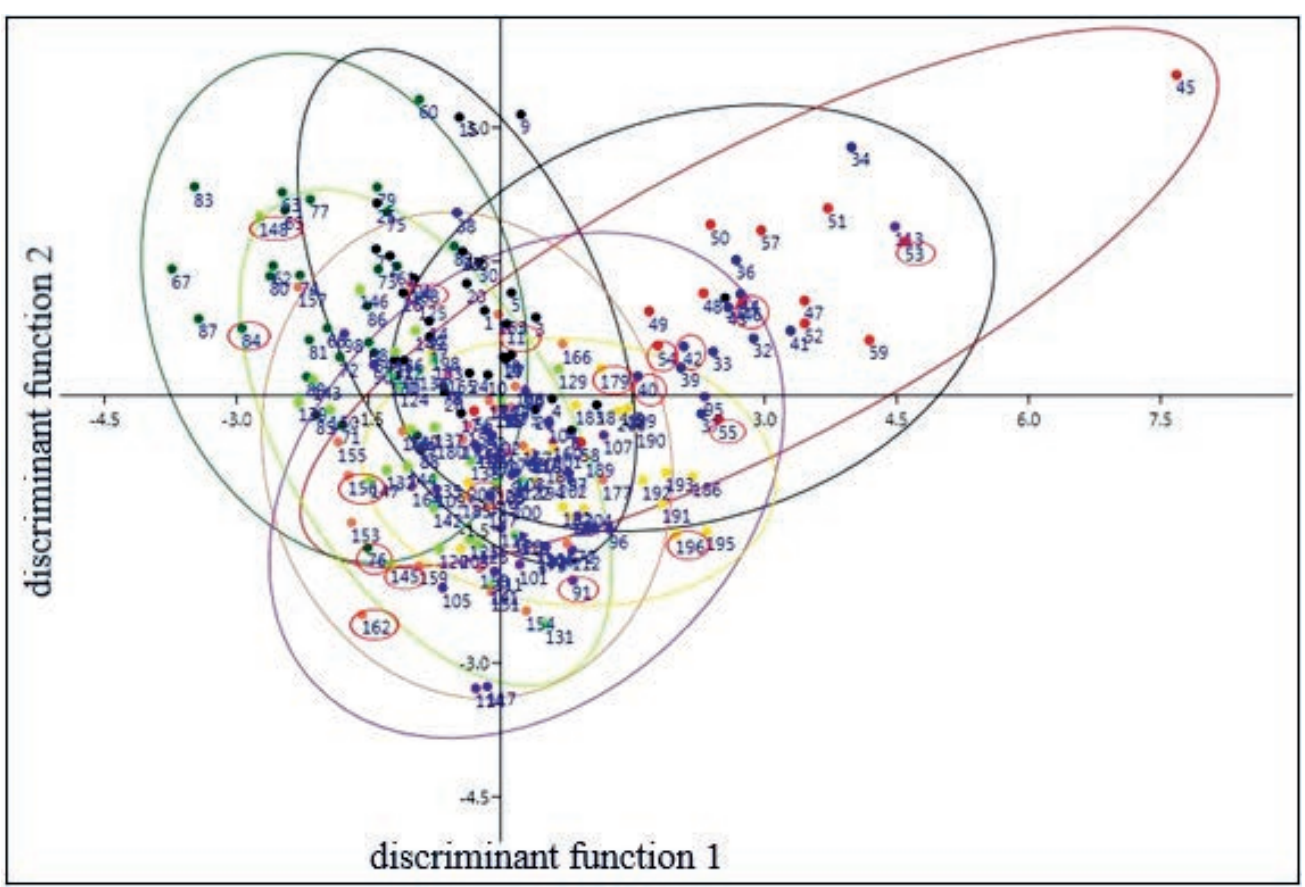

Figure 2. Scatterplot of the canonical scores of researched populations for the first two discriminant functions. Black: AY, Blue: AH, Red: TS, Dark green: GE, Blue violet: KT, Chartreuse: BA, Coral: AC, Gold: EC.

Slika 2. Projekcija kanoničkih vrijednosti istraživanih populacija u prostor prvih dviju diskriminantnih funkcija. Crna: AY; Plava: AH; Crvena: TS; Tamnozelena: GE; Plavo-ljubičasta: KT; Chartreuse: BA; Koraljno-crvena: AC; Zlatna: EC. 
the second discriminant function explained $29.0 \%$. The discriminant analysis showed that the trees from eight natural populations of Scots pine in Turkey cannot be clearly separated.

\section{DISCUSSION AND CONCLUSIONS RASPRAVA I ZAKLJUČCI}

The conducted research established significant variability of the morphological characteristics of Scots pine populations in Turkey. Statistically significant differences between the trees within and between populations were confirmed for all studied characteristics, except for the sheath length. In general, the morphological traits of needles appeared to be a useful tool for estimating pine species variability (Irvine et al. 1998; Niinemets et al. 2001; Pensa et al. 2004; Pravdin 1969; Żelawski and Niwiński 1966; Paule 1971; Urbaniak et al. 2003; Androsiuk et al. 2011; Jasińska et al. 2014; Poljak et al. 2020).

It is well known that phenotypic differences among populations are often a result of the environmental distances between populations (Dewoody et al. 2015; Poljak et al. 2012, 2014, 2018; Zebec et al. 2014). This is because the distribution of plant species depends highly on their competitive abilities to respond to environmental factors (Schoettle and Rochelle 2000). In some cases, morphological variability can be related to the altitude (Friend and Woodward 1990; Schoettle and Rochelle 2000; Poljak et al. 2015, 2018, 2020; Zebec et al. 2015). Specific gradient i.e. changes in morphological variability related to the change in altitude have been reported for Scots pine populations in Turkey (Turna and Güney 2009) and Croatia (Poljak et al. 2020). The mentioned authors stated that populations from lower altitudes had smaller cones as compared to the populations from higher altitudes. The present study revealed that needle length, needle width and the ratio of needle length to needle width significantly vary depending on altitude. In general, we reveled that populations from lower elevations were characterized with lager needles than the populations from higher altitudes. This may be related to the capacity of trees to adapt to environmental variation, which causes morphological changes in plant species and also facilitates the successful survival of plants subjected to new environmental conditions (Abrams 1990; Ellsworth and Reich 1992; Kubiske and Abrams 1992; Lei and Lechowicz 1997; Teklehaimanot et al. 1998; Aranda et al. 2001). Similarly, needle length of P. roxburghii Sarg. from the northwestern Indian Himalayas significantly correlated with altitude (Tiwari et al. 2013). Furthermore, differences in the morphological and anatomical properties of cones, needles and seeds along altitudinal and longitudinal gradients were reported in four populations of $P$. brutia Ten. by Dangasuk and Panetsos (2004). In addition, Xu et al. (2016) noted that needle length and the ratio of needle length to fascicle sheath length showed clinal variation in response to latitudinal and altitudinal gradients in P. yunnanensis Franch.

The results of the cluster and discriminant analysis did not confirmed divergence between the populations from different habitat zones from Turkey. Moreover, microclimatic effects that depended on existing geological structures, even when very short distances are considered, can result with significant interpopulation variability of Scots pine populations in Turkey (Ergül Bozkurt 2017). According to Kantarc1 (2005), vicinities in which Bolu, Kastamonu, Ankara and Eskişehir are found share similar ecological conditions. However, samples collected from these localities were not distinctly separated from the rest of the samples examined via multivariate statistical analysis.

According to reports within the Flora of Turkey and the East Aegean Islands (Davis et al. 1984), only P. sylvestris var. hamata is naturally distributed in Turkey. However, Farjon (2008) noted that $P$. sylvestris var. sylvestris and P. sylvestris var. hamata are naturally distributed in Turkey. In addition, Kandemir and Mataraci (2018), described a new variety of P. sylvestris, var. elicinii Kandemir and Matarac1, based on needle length from a Sürmene-Çamburnu population (TS). However, average, minimum, and maximum values of needle length of the TS population are closely related to Artvin-Arhavi (AH) and Kastamonu-Taşköprü (KT) populations. Additionally, present findings inferred from multivariate statistical analysis did not support the separation of TS population. In general, our result does not support the validity of different subspecies and variates of Scots pine in Turkey. In addition, Jasińska et al. (2014) reported that the morphological needle and cone characteristics of $P$. sylvestris varied among the populations of Iberia, Anatolia, the Balkans, and Crimea. Nevertheless, their results did not confirm the existence of $P$. sylvestris subsp. sylvestris and $P$. sylvestris subsp. hamata.

We observed significant phenotypic differentiation of studied populations of $P$. sylvestris in Turkey. Those populations represent the valuable relict genetic resources that are of high conservation priority. To confirm the conclusions reached on the variability of the Scots pine populations obtained by morphometric methods, the research also needs to be extended to molecular methods.

\section{ACKNOWLEDGMENTS}

\section{ZAHVALE}

We would like to express our special appreciation to staff of Forest Enterprises of Ardahan, Artvin (Arhavi, Hopa), Trabzon (Sürmene), Giresun (Espiye), Kastamonu (Taşköprü), Bolu (Karacasu-Aladağ), Ankara (Çamlıdere) and Eskişehir (Çatacık) for their kind assistance with the field studies. 


\section{REFERENCES}

\section{LITERATURA}

- Abrams, M.D., M.E. Kubiske, K.C. Steiner, 1990: Drought adaptations and responses in five genotypes of Fraxinus pennsylvanica Marsh: photosynthesis, water relations and leaf morphology, Tree Physiology, 6: 305-315.

- Alemdağ, Ş., 1967: Türkiye’deki Sarıçam ormanlarının kuruluşu, verim gücü ve bu ormanların işletilmesinde takip edilecek esaslar, Ormancılık Araştırma Enstitüsü Yayınları, Teknik Bülten Serisi, Güzel İstanbul Matbaası, 20 pp., Ankara, Turkey.

- Androsiuk, P., Z. Kaczmarek, L. Urbaniak, 2011: The morphological traits of needles as markers of geographical differentiation in European Pinus sylvestris populations, Dendrobiology, 65: 3-16.

- Aranda, I., L.F. Bergasa, L. Gil, J.A. Pardos, 2001: Effects of relative irradiance on the leaf structure of Fagus sylvatica L. seedlings planted in the understory of a Pinus sylvestris L. stand after thinning, Annals of Forest Science, 58: 673-680.

- Bilgen, B.B., N. Kaya, 2007: Allozyme variations in six natural populations of Scots pine (Pinus sylvestris L.) in Turkey, Biologia, 62: 697-703.

- Dangasuk, O.G., K.P. Panetsos, 2004: Altitudinal and longitudinal variations in Pinus brutia (Ten.) of Crete Island, Greece: some needle, cone and seed traits under natural habitats, New Forests, 27: 269-284.

- Davis PH, Cullen J, Coode MJE. 1984. Flora of Turkey and the East Aegean Islands Vol I (ed. by PH Davis, J Cullen \& MJE Coode) Edinburgh University Press, Edinburgh, pp. 72-5.

- Demirci, A., 2006: Silvikültürün temel ilkeleri, K.T.Ü. Orman Fakültesi, Ders Notları Serisi No: 83, K.T.Ü. Basımevi, 198 pp., Trabzon, Turkey.

- Dering, M., P. Kosiński, T.P. Wyka, E. Pers-Kamczyc, A. Boratyński, K. Boratyńska, P.B. Reich, A. Romo, M. Zadworny, R. Żytkowiak, J. Oleksyn, 2017: Tertiary remnants and Holocene colonizers: Genetic structure and phylogeography of Scots pine reveal higher genetic diversity in young boreal than in relict Mediterranean populations and a dual colonization of Fennoscandia, Diversity and Distributions, 23 (5): 1-16.

- Dewoody, J., H. Trewin, G. Taylor, 2015: Genetic and morphological differentiation in Populus nigra L.: isolation by colonization or isolation by adaptation? Molecular Ecology, 24: 26412655.

- Eliçin, G., 1971: Türkiye sarıçam (Pinus sylvestris L.) ormanlarında morfogenetik araştırmalar, [Recherches morphogenetiques sur les pins sylvestres de Turquie.], Istanb. Univ. Orman Fak. Yayinlari, 149: 143-149.

- Ellsworth, D.S., P.B. Reich, 1992: Water relations and gas Exchange in Acer saccharum seedlings in contrasting natural light and water regimes, Tree Physiology, 10: 1-20.

- Ergül Bozkurt, A., 2017: Sarıçam’ın (Pinus sylvestris L.) Türkiye'deki farklı yetişme ortamı bölgelerinde loristic, fitososyolojik ve ekolojik yönlerden araştırılması, Doktora Tezi, KTÜ Fen Bilimleri Enstitüsü, Trabzon, Turkey.

- Farjon, A., 2008: A natural history of conifers. Timber Press, 304 pp., Portland, Oregon.

- Friend, A.D., F.I. Woodward, 1990: Evolutionary and ecophysiological responses of mountain plants to the growing season environment, Advances in Ecological Research, 20: 59-124.
- Gaussen, H., 1960: Les Gymnospermes actuelles et fossils, Trav Labor Forestal Touluse 4.

- Hammer, Ø., D.A. Harper, P.D. Ryan, 2001: PAST: paleontological statistics software package for education and data analysis, Palaeontologia electronica, 4: 9.

- Houston Durrant, T., D. de Rigo, G. Caudullo, 2016: Pinus sylvestris in Europe: distribution, habitat, usage and threats. In: J. San-Miguel-Ayanz, D. de Rigo, G. Caudullo, T. Houston Durrant, A. Mauri, (Eds.), European Atlas of Forest Tree Species, Publ. Off. EU, Luxembourg, pp. e016b94+.

- IBM Corp., 2015: IBM SPSS Statistics for Windows, Version 23.0. IBM corp: Armonk, NY. Available online at: http://www01.ibm.com/support/docview.wss?uid=swg24038592.

- Irvine, J., M.P. Perks, F. Magnani, J. Grace, 1998: The response of Pinus sylvestris to drought: stomatal control of transpiration and hydraulic conductance, Tree Physiology, 18: 393-402.

- Jasińska, A.K., K. Boratyńska, M. Dering, K.I. Sobierajska, T. Ok, A. Romo, A. Boratyński, 2014: Distance between southEuropean and south-west Asiatic refugial areas involved morphological differentiation: Pinus sylvestris case study, Plant Systematics and Evolution 300: 1487-1502.

- Kandemir, A., T. Matarac1, 2018: Pinus L., Resimli Türkiye Florası (Illustrated Flora of Turkey), Vol 2. (eds., A. Güner, A. Kandemir, Y. Menemen, H. Yıldırım, S. Aslan, G. Ekşi, I. Güner, A.Ö. Çimen), ANG Vakfı Nezahat Gökyiğit Botanik Bahçesi Yayınları, 324-354 pp., İstanbul, Turkey.

- Kantarc1, M.D., 2005: Türkiye'nin yetişme ortamı bölgesel sınıflandırması ve bu birimlerdeki orman varlığı ile devamlılığının önemi, İstanbul Üniversitesi Orman Fakültesi Yayını, İ.Ü. Yayın Nu: 4558, OF. Yayın Nu: 484, İstanbul Üniversitesi Basım ve Yayınevi Müdürlüğü, ISBN Nu: 975-404-752-9, İstanbul, Turkey.

- Kayacık, H., 1954: Türkiye çamları ve bunların coğrafi yayılışları üzerinde araştırmalar, Orman Fakültesi Dergisi, 1-2: 44-64.

- Koprowski, M., R. Przybylak, A. Zielski, A. Pospieszyńska 2012: Tree rings of Scots pine (Pinus sylvestris L.) as a source of information about past climate in northern Poland, International Journal of Biometeorology, 56: 1-10.

- Krauze-Michalska, E., K. Boratyńska, 2013: European geography of Alnus incana leaf variation, Plant Biosystems, 147 (3): 601-610.

- Kubiske, M.E., M.D. Abrams, 1992: Photosynthesis, water relations, and leaf morphology of xeric versus mesic Quercus rubra ecotypes in central Pennsylvania in relation to moisture stress, Canadian Journal of Forest Research, 22: 1402-1407.

- Lei, T.T., M.J. Lechowicz, 1997: The photosynthetic response of eight species of Acer to simulated light regimes from the center and edges of gaps, Functional Ecology, 11: 16-23.

- Mátyás, C., L. Ackzelland, C.J.A. Samuel, 2004: EUFORGEN Technical Guidelines for genetic conservation and use for Scots pine (Pinus sylvestris), International Plant Genetic Resources Institute, 6 pp., Rome, Italy.

- McGarigal, K., S. Stafford, S. Cushman, 2000: Discriminant analysis. In Multivariate statistics for wildlife and ecology research (pp. 129-187). Springer, New York, NY.

- Mirov, N.T., 1967: The genus Pinus, Ronald Press, 602 pp., New York.

- Naydenov, K., S. Senneville, J. Beaulieu, F. Tremblay, J. Bousquet, 2007: Glacial vicariance in Eurasia: Mitochondrial DNA evi- 
dence from Scots pine for a complex heritage involving genetically distinct refugia at mid-northern latitudes and in Asia Minor, BMC Evolutionary Biology, 7, 233.

- Nie, N.H., C.H. Hull, J.G. Jenkins, K. Steinbrenner, D.H. Bent, 1975: SPSS: statistical package for the social sciences, $2^{\text {nd }} e d$., McGraw-Hill Book Company, New York.

- Niinemets, U., D.S. Ellsworth, A. Lukjanova, M. Tobias, 2001: Site fertility and the morphological and photosynthetic acclimation of Pinus sylvestris needles to light, Tree Physiology, 21: 1231-1244.

- Pamay, B., 1962: Türkiye'de Sarıçam (Pinus sylvestris L.)'ın tabii gençleşmesi imkanları üzerinde araştırmalar, Tarım Bakanlığı Orman Genel Müdürlüğ̈u, 196 pp., Ankara, Turkey.

- Paule, L., 1971: Anatomical and morphological variability of Scots pine, Zbornik Vadeckych Prac Lesnickej Fakulty Vysokej Skoly Lesnickej a Drevarskej vo Zvolene, 13: 111-128.

- Pehlivan, S., 2010: Sarıçam (Pinus sylvestris L.)'in ağaç hacim tablolarının düzenlenmesi, Yüksek Lisans Tezi, KTÜ Fen Bilimleri Enstitüsü, Trabzon, Turkey.

- Pensa, M., T. Aalto, R. Jalkanen, 2004: Variation in needle-trace trunk radius in respect of needle morphology in five conifer species, Trees-Structure and Function, 18: 307-311.

- Podani, J., 2001: SYN-TAX 2000, Computer programs for data analysis in ecology and systematics, User's manual, Scientia, 452 pp., Budapest, Hungary.

- Poljak, I., M. Idžojtić, M. Zebec, N. Perković, 2012: The variability of European sweet chestnut (Castanea sativa Mill.) in the region of northwest Croatia according to morphology of fruits, Sumar List, 136 (9-10): 479-489.

- Poljak, I., M. Idžojtić, I. Šapić, J. Vukelić, M. Zebec, 2014. Population variability of grey (Alnus incana /L./ Moench) and black alder (A.glutinosa /L./ Gaertn.) in the Mura and Drava region according to the leaf morphology, Sumar List, 138 (1-2): 7-17.

- Poljak, I., D. Kajba, I. Ljubić, M. Idžojtić, 2015: Morphological variability of leaves of Sorbus domestica L. in Croatia, Acta Societatis Botanicorum Poloniae, 84 (2): 249-259.

- Poljak, I., M. Idžojtić, I. Šapić, P. Korijan, J. Vukelić, 2018: Diversity and Structure of Croatian Continental and Alpine-Dinaric Populations of Grey Alder (Alnus incana L. Moench subsp. incana): Isolation by Distance and Environment Explains Phenotypic Divergence, Sumar List, 142 (1-2): 19-32.

- Poljak, I., J. Vukelić, A. Vidaković, M. Vuković, M. Idžojtić, 2020: Variability of the populations of Scots pine (Pinus sylvestris L.) in the northwestern part of Mala Kapela according to the morphological characteristics of the needles and cones, Sumar List, 144 (11-12).

- Pravdin, L.F., 1969: Scots pine variation, intraspecific taxonomy and selection, Annarbor Humphrey Science Publishers Ltd., 208 pp., London, United Kingdom of Great Britain and Northern Ireland.

- Pyhäjärvi, T., M.J. Salmela, O. Savolainen, 2008: Colonization routes of Pinus sylvestris inferred from distribution of mitochondrial DNA variation, Tree Genetics and Genomes, 4, 247254.

- Ruby, J. L., 1967: The correspondence between genetic, morphological, and climatic variation patterns in Scots pine I. Variations in parental characters, Silvae Genetica, 16: 50-56.
- Saatçioğlu, F., 1944: Yerli ve yabancı Sarıçam (Pinus silvestris) tohumlarıyla yapılan denemeler ve şimdiye kadar alınan sonuçlar, Yüksek Ziraat Enstitüsü Dergisi, Sayı 2.

- Schoettle, A.W., S.G. Rochelle, 2000: Morphological variation of Pinus flexilis (Pinaceae), a bird-dispersed pine, across a range of elevations, American Journal of Botany, 87: 1797-1806.

- Sinclair, W.T., J.D. Morman, R.D. Ennos, 1998: Multiple origins for Scots pine (Pinus sylvestris L.) in Scotland: Evidence from mitochondrial DNA variation, Heredity, 80: 233-240.

- Sinclair, W.T., J.D. Morman, R.D. Ennos, 1999: The postglacial history of Scots pine (Pinus sylvestris L.) in western Europe: Evidence from mitochondrial DNA variation, Molecular Ecology, 8: 83-88.

- Sokal, R.R., F.J. Rohlf, 2012: Biometry: the principles and practice of statistics in biological research, $4^{\text {th }}$ edition, W.H. Freeman and Co., 937 pp., New York.

- Szmidt, A.E., 1984: Genetic studies of Scots pine (Pinus sylvestris L.) domestication by means of isozyme analysis, Phd Thesis, The Swedish University of Agricultural Sciences, Department of Forest Genetics and Plant Phsiology, Umea.

- Teklehaimanot, Z., J. Lanek, H.F. Tomlinson, 1998: Provenance variation in morphology and leaflet anatomy of Parkia biglobosa and its relation to drought tolerance, Trees, 13: 96-102.

- Tiwari, S.P., P. Kumar, D. Yadav, D.K. Chauhan, 2013: Comparative morphological, epidermal, and anatomical studies of Pinus roxburghii needles at different altitudes in the North-West Indian Himalayas, Turkish Journal of Botany, 37: 65-73.

- Turna, I., D. Güney, 2009: Altitudinal variation of some morphological characters of Scots pine (Pinus sylvestris L.) in Turkey, African Journal of Biotechnology, 8 (2): 202-208.

- Urbaniak, L., L. Karliński, R. Popielarz, 2003: Variation of morphological needle characters of Scots pine (Pinus sylvestris L.) populations in different habitats, Acta Societatis Botanicorum Poloniae, 72: 37-44.

- Wang, X.R., A.E. Szmidt, D.A.G. Lindgren, 1991: Allozyme differentiation among populations of Pinus sylvestris L. from Sweden and China, Hereditas, 114: 219-226.

- Wright, J.W., W.I. Bull, 1963: Geographic variation in Scots pine: results of a 3-year Michigan study, Silvae Genetics, 12: 1-25.

- Xu, Y., K. Woeste, N. Cai, X. Kang, G. Li, S. Chen, A. Duan, 2016: Variation in needle and cone traits in natural populations of Pinus yunnanensis, Journal of forestry research, 27 (1): 41-49.

- Zebec, M., M. Idžojtić, I. Poljak, I. Mihaldinec, 2010: The variability of field elm (Ulmus minor Mill. sensu latissimo) in Croatian Drava river valley according to the leaf morphology, Sumar List, 134 (11-12): 569-580.

- Zebec, M., M. Idžojtić, I. Poljak, 2014: Morphological variability of the feld elm (Ulmus minor Mill. sensu latissimo) in continental Croatia, Sumar List, 138 (11-12): 563-572.

- Zebec, M., M. Idžojtić, I. Poljak, I. Modrić, 2015: Population variability of wych elm (Ulmus glabra Huds.) in the mountainous region of Croatia according to the leaf morphology, Sumar List, 139 (9-10): 429-439.

- Żelawski, W., Z. Niwiński, 1966: Variability of some needles characteristics in Scots pine (Pinus sylvestris L.) ecotypes, grown in native conditions, Ekologia Polska, 14: 301-30. 


\section{SAŽETAK}

U radu je istražena varijabilnost prirodnih populacija običnoga bora (Pinus sylvestris L., Pinaceae) u Turskoj s obzirom na morfologiju iglica. U istraživanje je ukupno uključeno osam populacija, 206 stabala i 1314 iglica. Kako bi se utvrdila raznolikost i strukturiranost populacija izmjerene su i analizirane četiri značajke iglica. Istraživanjem je utvrđena značajna varijabilnost te da se istraživane populacija, kao i stabla unutar populacija, statistički značajno razlikuju. Izuzetak čini značajka dužina rukavca za koju nisu potvrđene razlike na međupopulacijskoj razini. Dobiveni rezultati također upućuju na to da značajke dužina i širina iglice te odnos dužine i širine iglice pokazuju klinalnu varijabilnost s obzirom na nadmorsku visinu. Populacije s viših nadmorskih visina odlikovale su se kraćim i debljim iglicama u odnosu na populacije s nižih nadmorskih visina. Općenito, rezultati ovog istraživanja mogu poslužiti kao vrijedna osnova za određivanje i razvijanje smjernica za učinkovitije planove gospodarenja ovom važnom šumskom vrstom drveća.

KLJUČNE RIJEČI: obični bor, populacijska varijabilnost, svojstva iglica, morfometrijska analiza, klinalna varijabilnost 